\title{
Peningkatan Kesadaran Masyarakat dalam Penggunaan Alat Kontrasepsi di Kelurahan Kenali Asam Bawah
}

\author{
Safitri \\ Prodi D III Kebidanan STIKes Baiturrahim Jambi \\ Email: safitrypipit@gmail.com
}

Submitted : 28/11/2019

Accepted: 05/12/2019

Published: 31/01/2020

\begin{abstract}
Contraception is defined as the intentional prevention of conception through the use of various devices, sexual practices, chemicals, drugs, or surgical procedures. Contraceptive is device or act whose purpose is to prevent a woman from becoming pregnant. The choice of contraception in Kelurahan Kenali Asam Bawah is dominated by short-term contraception methods (injections and pills by 88\%). In addition, there are still couples of childbearing age who do not use contraception by $22.2 \%$ on the grounds of not knowing $17.5 \%, 61.7 \%$ uncomfortable, religiously prohibited $16.7 \%$ and expensive $4.1 \%$. Health education by trained health workers can increase knowledge and encourage fertile age couples to make decisions in using appropriate and effective contraception. Target outcomes expected are: there is an increased knowledge between before and after counseling, as well as awareness to use contraception. The method used is counseling. The results of dedication are an increase in knowledge of women of childbearing age and awareness to use safer contraceptives, so that community coverage related to long-term contraception is increased.
\end{abstract}

Keywords: awareness, contraceptive, health education

\begin{abstract}
ABSTRAK
Kontrasepsi didefinisikan sebagai pencegahan konsepsi yang disengaja melalui penggunaan berbagai alat, praktik seksual, bahan kimia, obat-obatan atau prosedur bedah. Alat kontrasepsi adalah alat atau tindakan apapun untuk mencegah kehamilan. Pemilihan jenis alat kontrasepsi di Kelurahan Kenali Asam Bawah didominasi oleh metode kontrasepsi jangka pendek (suntikan dan pil sebesar 88\%). Selain itu, masih ada juga pasangan usia subur yang tidak menggunakan alat kontrasepsi sebesar $22,2 \%$ dengan alasan tidak tahu $17,5 \%$, tidak nyaman $61,7 \%$, dilarang agama $16,7 \%$ dan mahal $4,1 \%$. Pendidikan kesehatan oleh tenaga kesehatan terlatih dapat meningkatkan pengetahuan dan mendorong pasangan usia subur untuk mengambil keputusan dalam menggunakan alat kontrasepsi yang tepat dan efektif. Target luaran yang diharapkan peningkatan pengetahuan antara sebelum dan setelah penyuluhan, serta kesadaran untuk menggunakan alat kontrasepsi. Metode yang digunakan adalah penyuluhan. Hasil pengabdian terdapat peningkatan pengetahuan wanita usia subur dan kesadaran untuk menggunakan alat kontrasepsi yang lebih aman, sehingga cakupan masyarakat terkait alat kontrasepsi jangka panjang meningkat.
\end{abstract}

Kata Kunci: alat kontrasepsi, kesadaran masyarakat, pendidikan kesehatan

\section{PENDAHULUAN}

Indonesia merupakan salah satu negara berkembang dengan berbagai jenis masalah kependudukan. Masalah utamanya yaitu peningkatan jumlah penduduk yang sulit dikontrol beberapa tahun terakhir ini. Menurut World Population Data Sheet 2018, Indonesia merupakan negara ke-4 di dunia dengan estimasi jumlah penduduk terbanyak, yaitu 265 juta jiwa. Pusat Data Informasi, Kementerian Kesehatan RI, mengestimasi jumlah penduduk Indonesia tahun 2017 sejumlah 261,8 juta jiwa (Kemenkes RI, 2018).

Kebijakan pemerintah dalam mengatasi hal tersebut melalui Peraturan Pemerintah Republik Indonesia Nomor 87 Tahun 2014 tentang Perkembangan 
Kependudukan dan Pembangunan Keluarga, Keluarga Berencana, dan Sistem Informasi Keluarga menyebutkan bahwa program keluarga berencana (KB) adalah upaya mengatur kelahiran anak, jarak dan usia ideal melahirkan, mengatur kehamilan, melalui promosi, perlindungan, dan bantuan sesuai hak reproduksi untuk mewujudkan keluarga yang berkualitas. Sasaran pelaksanaan program KB yaitu Pasangan Usia Subur (PUS). PUS adalah pasangan suami-istri yang terikat dalam perkawinan yang sah, yang istrinya berumur antara 15 sampai dengan 49 tahun. Pelayanan KB meliputi penyediaan informasi, pendidikan, dan cara-cara bagi keluarga untuk dapat merencanakan kapan akan mempunyai anak, berapa jumlah anak, berapa tahun jarak usia antara anak, serta kapan akan berhenti mempunyai anak (Kemenkes RI, 2018).

Kontrasepsi didefinisikan sebagai pencegahan konsepsi yang disengaja melalui penggunaan berbagai alat, praktik seksual, bahan kimia, obat-obatan atau prosedur bedah. Alat kontrasepsi adalah alat atau tindakan apapun untuk mencegah kehamilan. Kontrasepsi yang efektif memungkinkan pasangan untuk melakukan hubungan seksual tanpa takut akan kehamilan yang tidak diinginkan dan memastikan untuk memiliki anak yang diinginkan. Kontrasepsi bertujuan mencapai kenyamanan dan meminimalisir biaya dan efek samping (Rakhi, 2011).

Beragam pilihan metode kontrasepsi hormonal dan non-hormonal dapat digunakan untuk mencegah kehamilan sesuai dengan situasi dan keinginan pengguna. Pemilihan kontrasepsi dapat dipengaruhi oleh efek samping yang dialami, kemudahan penggunaan, perlindungan pribadi dari infeksi menular seksual (IMS), dan sensitivitas lateks. Pertimbangan lain termasuk kenyamanan, aksesibilitas produk, kemanjuran, dan keterjangkauan (Colquitt, 2017).
Berdasarkan pola dalam pemilihan jenis alat kontrasepsi, sebagian besar peserta $\mathrm{KB}$ Aktif memilih suntikan dan pil sebagai alat kontrasepsi bahkan sangat dominan (lebih dari $80 \%$ ) dibanding metode lainnya; suntikan $(62,77 \%)$ dan pil $(17,24 \%)$. Padahal suntikan dan pil termasuk dalam metode kontrasepsi jangka pendek sehingga tingkat efektifitas suntikan dan pil dalam pengendalian kehamilan lebih rendah dibandingkan jenis kontrasepsi lainnya. Penggunaan Metode Kontrasepsi Jangka Panjang (MKJP) masih sangat rendah dikarenakan pengetahuan masyarakat yang masih rendah tentang kelebihan metode MKJP dan keterbatasan jumlah tenaga terlatih serta sarana yang ada. Dari keseluruhan jumlah peserta $\mathrm{KB}$ aktif, hanya $17,45 \%$ diantaranya yang menggunakan $\mathrm{KB}$ MKJP. Sedangkan $81,23 \%$ lainnya pengguna $\mathrm{KB}$ non MKJP dan 1,32\% menggunakan metode $\mathrm{KB}$ tradisional (Kemenkes RI, 2018).

Kelurahan Kenali Asam Bawah merupakan salah satu kelurahan yang berada di Kecamatan Kota Baru. Di Kelurahan Kenali Asam Bawah pemilihan alat kontrasepsi juga didominasi oleh suntikan dan pil $(88 \%)$; suntikan $(31,9 \%)$ dan pil $(56,2 \%)$. Penggunaan alat kontrasepsi MKJP sebesar 9\%, non MKJP sebesar $89,3 \%$ dan metode $\mathrm{KB}$ tradisional sebesar $1,7 \%$. Selain itu, masih ada juga PUS yang tidak menggunakan alat kontrasepsi sebesar 22,2\% dengan alasan tidak tahu $17,5 \%$, tidak nyaman $61,7 \%$, dilarang agama $16,7 \%$ dan mahal $4,1 \%$.

Pendidikan kesehatan yang diberikan oleh tenaga kesehatan terlatih dapat membantu mencegah kehamilan yang tidak diinginkan dengan mendorong PUS untuk mengambil keputusan dalam menggunakan alat kontrasepsi yang tepat dan efektif berdasarkan informasi dasar tentang alat kontrasepsi. Pentingnya pendidikan kesehatan tentang kontrasepsi dapat dilihat dari dampak pengetahuan pada pemilihan dan penggunaan alat kontrasepsi. 
Efektivitas kontrasepsi merupakan salah satu pertimbangan yang paling penting ketika pasangan memilih metode kontrasepsi. Pengetahuan yang baik tentang efektivitas kontrasepsi berkaitan dengan peningkatan kesadaran penggunaan alat kontrasepsi, sebaliknya pengetahuan kontrasepsi yang rendah dan persepsi yang salah tentang risiko dan efek samping alat kontrasepsi membuat pasangan menggunakan kontrasepsi secara tidak tepat, tidak konsisten, bahkan menghentikan penggunaan alat kontrasepsi (Pazol, 2015).

Berdasarkan paparan diatas maka penulis tertarik mengangkat judul "Peningkatan Kesadaran Masyarakat dalam Penggunaan Alat Kontrasepsi di Kelurahan Kenali Asam Bawah”.

\section{TARGET DAN LUARAN}

Target dalam kegiatan pengabdiaan kepada masyarakat ini adalah memberikan pendidikan kesehatan kepada wanita usia subur tentang keluarga berencana dan kontrasepsi. Adapun luaran dalam kegiatan pengabdian kepada masyarakat ini adalah publikasi pada jurnal ilmiah serta meningkatkan pengetahuan wanita usia subur tentang keluarga berencana dan kontrasepsi dengan harapan wanita usia subur beserta pasangan mampu mengambil keputusan dalam menggunakan alat kontrasepsi yang aman, tepat dan efektif. Sehingga meningkatnya kesadaran penggunaan alat kontrasepsi dan meningkatnya capaian penggunaan kontrasepsi jangka panjang.

\section{METODE PELAKSANAAN}

Pengabdian kepada masyarakat ini dilaksanakan pada bulan Januari-Februari 2019 di Kelurahan Kenali Asam Bawah. Sasaran kegiatan ini adalah wanita usia subur. Kegiatan pengabdian kepada masyarakat ini, mendapat rekomendasi dari Kepala Lurah Kenali Asam Bawah,
Puskesmas Paal X, Ketua RT dan Kader setempat untuk memberikan pendidikan kesehatan tentang keluarga berencana dan kontrasepsi melalui penyuluhan kepada wanita usia subur dengan metode ceramah disertai diskusi dan tanya jawab menggunakan media leaflet berisi informasi tentang keluarga berencana dan kontrasepsi. Pendidikan kesehatan yang dilakukan merupakan kegiatan atau usaha untuk menyampaikan informasi tentang keluarga berencana dan kontrasepsi kepada wanita usia subur meliputi pengertian keluarga berencana, manfaat keluarga berencana, sasaran keluarga berencana, dan metode kontrasepsi.

Tahapan kegiatan pengabdian kepada masyarakat meliputi:

1. Mengkaji dan menganalisis data

2. Mengidentifikasi masalah

3. Menyusun rencana kegiatan

4. Menyusun SAP, materi, instrumen preposttest serta mendesain leaflet

5. Mengurus izin lokasi kegiatan

6. Melakukan pretest

7. Memberikan pendidikan kesehatan melalui penyuluhan tentang keluarga berencana dan kontrasepsi kepada wanita usia subur menggunakan leaflet sesuai SAP yang telah disusun

8. Melakukan posttest

9. Melakukan monitoring dan evaluasi

\section{HASIL PEMBAHASAN}

Pelaksanaan kegiatan pengabdian kepada masyarakat berjalan sesuai dengan rencana yang disusun. Kegiatan ini dilakukan pada kegiatan pengajian ibu-ibu di Kelurahan Kenali Asam Bawah. Dalam pelaksanaan kegiatan ini Tim dibantu oleh ibu RT dan kader yang sedang bertugas di wilayah tersebut.

Sebelum dilakukan penyuluhan tentang keluarga berencana dan kontrasepsi, $56,7 \%$ ibu mampu menjelaskan pengertian keluarga berencana, $40 \%$ ibu mampu menyebutkan manfaat keluarga berencana, 
53,3\% ibu mampu menginformasikan sasaran keluarga berencana, dan $36,7 \%$ ibu mampu menguraikan metode kontrasepsi. Metode kontrasepsi hanya diketahui beberapa jenis alat kontrasepsi saja dan yang paling sering digunakan di masyarakat yaitu suntik KB, pil KB, sedangkan penggunaan IUD dan susuk KB di Kenali Asam Bawah cakupannya masih sedikit, selain itu masyarakat belum mengetahui kelebihan dan kekurangan dari setiap alat kontrasepsi yang mereka gunakan.

Setelah dilakukan penyuluhan tentang keluarga berencana dan kontrasepsi, $86,7 \%$ ibu mampu menjelaskan pengertian keluarga berencana, 63,3\% ibu mampu menyebutkan manfaat keluarga berencana, 83,3\% ibu mampu menginformasikan sasaran keluarga berencana, dan $56,7 \%$ ibu mampu menguraikan metode kontrasepsi. Masyarakat lebih tahu dan dapat mempertimbangkan dan mengambil keputusan apakah alat kontrasepsi yang digunakan aman, tepat dan efektif sesuai dengan kebutuhan.

Selama proses penyuluhan terdapat ibu yang bertanya tentang kontrasepsi yang aman dan kami menjelaskan bahwa setiap kontrasepsi pasti memiliki efek samping yang perlu diperhatikan adalah sebelum menentukan alat kontrasepsi harapannya ibu melakukan pemeriksaan sebelumnya untuk memastikan apakah ibu bisa atau tidak menggunakan alat kontrasepsi pilihannya. Setelah diberikan penyuluhan tentang keluarga berencana dan kontrasepsi, masyarakat memahami tentang penggunaan Alat Kontrasepsi Jangka Panjang, mereka menjadi tahu jika alat kontrasepsi tidak hanya KB Pil dan Suntik saja. Pengetahuan tentang efek positif dan negatif dari penggunaan kontrasepsi juga meningkat jadi dapat memilih kontrasepsi yang lebih aman, sehingga cakupan masyarakat terkait alat kontrasepsi Jangka Panjang Meningkat.

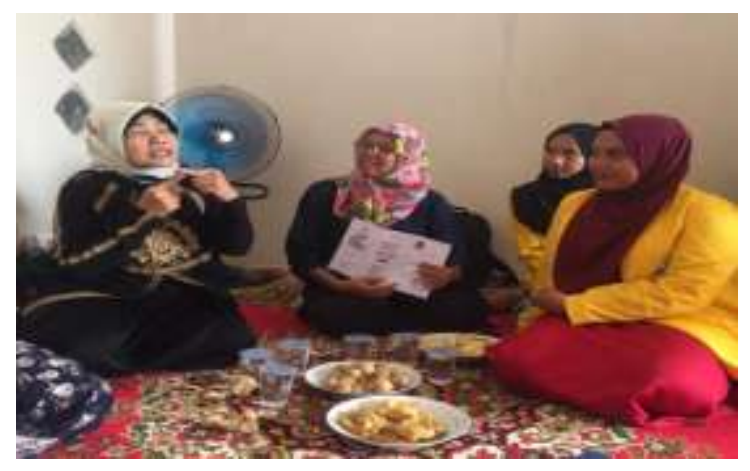

Gambar.1 Kegiatan pengabdian

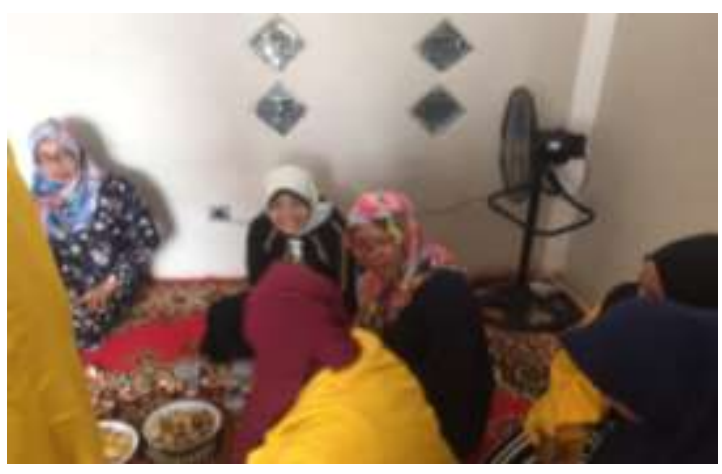

Gambar.2 Diskusi tentang kontrasepsi

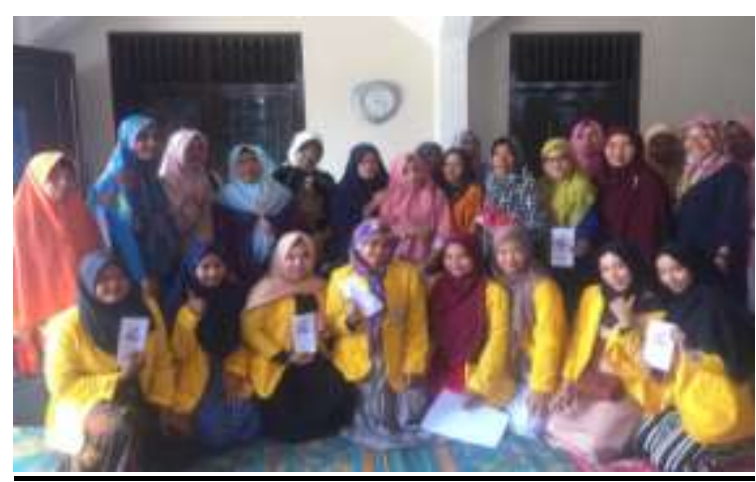

Gambar.3 Tim Pengabmas dan WUS

Hasil ini didukung oleh penelitian yang dilakukan sebelumnya oleh Hardiningsih, dkk (2017) yang berjudul Pengaruh Penyuluhan Terhadap Tingkat Pengetahuan Wanita Usia Subur Tentang Alat Kontrasepsi di Wilayah Kerja Puskesmas Sangkrah Kota Sukakarta dengan hasil ada pengaruh penyuluhan terhadap tingkat pengetahuan wanita usia subur tentang alat kontrasepsi ( $p$-value $=0,000<$ alpha 0,05 ). 
Penelitian lain yang dilakukan oleh Pazol dkk (2015) diketahui bahwa pendidikan kesehatan (penyuluhan) tentang kontrasepsi meliputi risiko, manfaat, efek samping, efektivitas, atau penggunaan yang benar berdampak terhadap peningkatan pengetahuan dan pengambilan keputusan dalam pemilihan metode kontrasepsi.

Penyuluhan merupakan pemberian informasi sebagai upaya untuk meningkatkan atau memelihara kesehatan. Pemberian penyuluhan kepada wanita usia subur tentang alat kontrasepsi sebagai upaya meningkatkan pengetahuan wanita usia subur tentang macam-macam alat kontrasepsi sehingga tidak hanya menggunakan kontrasepsi suntik saja. Menurut A Joint Committee on Terminology in Health Education of United States (1951) dalam Machfoedz dan Suryani (2008) pendidikan kesehatan (penyuluhan) adalah pengalaman belajar yang bertujuan untuk mempengaruhi pengetahuan, sikap dan perilaku yang ada hubungannya dengan kesehatan perseorangan atau kelompok (Hardiningsih, 2017).

Penelitian yang dilakukan oleh Diez dkk (2017), menunjukkan bahwa pemberian penyuluhan berdasarkan teori yang singkat dapat meningkatkan penggunaan kontrasepsi yang efektif pada masyarakat berpenghasilan rendah dengan proporsi imigrasi yang tinggi (Barcelona-Spanyol). Meningkatkan pengguna metode kontrasepsi yang efektif adalah strategi untuk mengurangi kehamilan yang tidak diinginkan. Pemberian penyuluhan kontrasepsi berdasarkan teori dan konsep perilaku telah direkomendasikan untuk mempromosikan metode kontrasepsi.

Pemberian informasi,melalui penyuluhan memegang peranan penting dalam mendukung usaha untuk meningkatkan angka cakupan KB yang rendah. Penyuluhan yang dilakukan secara terus menerus disertai dengan cara penyuluhan menarik, lama kelamaan akan meningkatkan rasa ingin tahu dan lebih jauh lagi menjadi kebutuhan. Bila penyuluhan sudah menjadi suatu kebutuhan seseorang, maka akan jauh lebih mudah untuk melakukan sosialisasi berbagai program kesehatan. Sejalan dengan perlunya informasi tentang kontrasepsi bagi wanita usia subur, maka penyuluhan dan pemberian leaflet perlu ditingkatkan lagi sehingga akseptor KB dapat meningkatkan pengetahuannya dan mengatur jarak kelahiran (Chasanah, 2014).

\section{KESIMPULAN DAN SARAN}

1. Kesimpulan

Pelaksanaan kegiatan pengabdian kepada masyarakat melalui pendidikan kesehatan tentang keluarga berencana dan kontrasepsi di Kelurahan Kenali Asam Bawah mampu meningkatkan pengetahuan wanita usia subur dan kesadaran untuk menggunakan alat kontrasepsi yang lebih aman, sehingga capaian penggunaan alat kontrasepsi jangka panjang meningkat.

\section{Saran}

Selain pendidikan kesehatan untuk peningkatan kesadaran tentang penggunaan alat kontrasepsi di Kelurahan Kenali Asam Bawah, diperlukan tenaga kesehatan dan kader secara aktif melakukan evaluasi pencapaian cakupan penggunaan alat kontrasepsi sehingga tenaga kesehatan dapat mendeteksi pasangan usia subur yang tidak aktif menggunakan dan menyarankan untuk menggunakan alat kontrasepsi yang aman, tepat dan efektif sesuai dengan kebutuhan.

\section{UCAPAN TERIMAKASIH}

Tim pengabdian masyarakat mengucapkan terima kasih yang sebesarbesarnya kepada STIKes Baiturrahim Jambi atas bantuan dana dan fasilitas surat izin. Serta Kepala Kelurahan Kenali Asam Bawah, Puskesmas Paal X, Ketua RT, Kader dan ibu-ibu setempat yang telah memfasilitasi dan memberikan izin tempat 
pengabdian kepada masyrakat ini, sehingga kegiatan pengabdian masyarakat ini dapat berjalan dengan lancar sesuai dengan waktu yang telah ditentukan.

\section{DAFTAR PUSTAKA}

Chasanah SU. Pemberian Leaflet dan Penyuluhan terhadap Peningkatan Pengetahuan Wanita Usia Subur tentang Alat Kontrasepsi KB. Jurnal Kesehatan Masyarakat. 2014 Mar;7(1):209-16.

Colquitt CW, Martin TS. Contraceptive Methods: A Review of Nonbarrier and Barrier Products. IJPP. 2017;30(1):130-5. DOI $10.1177 / 0897190015585751$.

Diez E, Lopez MJ, Dell'Olmo MM, Nebot L, Perez G, Villalbi JR, dkk. Effects of a Counselling Intervention to Improve Contraception in Deprived Neighbourhoods: a Randomized Controlled Trial. EJPH. 2017;28(1):10-5.

DOI:10.1093/eurpub/ckx046.

Hardiningsih, Yuneta AEN, Yunita FA. Pengaruh Penyuluhan terhadap Tingkat Pengetahuan Wanita Usia
Subur tentang Alat Kontrasepsi di Wilayah Kerja Puskesmas Sangkrah Kota Surakarta Jurnal KesMaDaSka. 2017 Jan.

Kementerian Kesehatan RI. 2018. Profil Kesehatan Indonesia 2017. Kesehatan Kementerian Kesehatan RI. Jakarta.

Population Reference Bureau. World Population Data Sheet 2018. 2018 [diunduh 28 Januari 2019]. Tersedia dari: URL: https://www.prb.org/wpcontent/uploads/2018/08/2018_WP DS.pdf.

Pazol K, Zapata LB, Tregear SJ, Smith NM, Gavin LE. Impact of Contraceptive Education on Contraceptive Knowledge and Decision Making: A Systematic Review. Am J Prov Med. 2015 August;49(201):S46-S56. doi:10.1016/j.amepre.2015.03.031.

Rakhi J, Sumathi M. Contraceptive Methods: Needs, Options and Utilization. JOGI. 2011 NovDec;61(6):626-34. DOI 10.1007/s13224-011-0107-7. 